\title{
What is the clinical course of patients hospitalised for COVID-19 treatment Ireland: a retrospective cohort study in Dublin's North Inner City (the 'Mater $\left.100^{\prime}\right)$
}

\section{Research Article}

Keywords:

Posted Date: January 27th, 2021

DOl: https://doi.org/10.21203/rs.3.rs-34035/v2

License: (1) This work is licensed under a Creative Commons Attribution 4.0 International License. Read Full License

Version of Record: A version of this preprint was published at HRB Open Research on November 6th, 2020. See the published version at https://doi.org/10.12688/hrbopenres.13138.1. 


\section{Abstract}

The authors have requested that this preprint be withdrawn due to a need to make corrections.

\section{Full Text}

The authors have withdrawn this preprint from Research Square. 